\title{
DISENTANGLING DEMAND-ENHANCING AND TRADE-COST EFFECTS OF MAXIMUM RESIDUE REGULATIONS
}

Bo Xiong, John C. Beghin

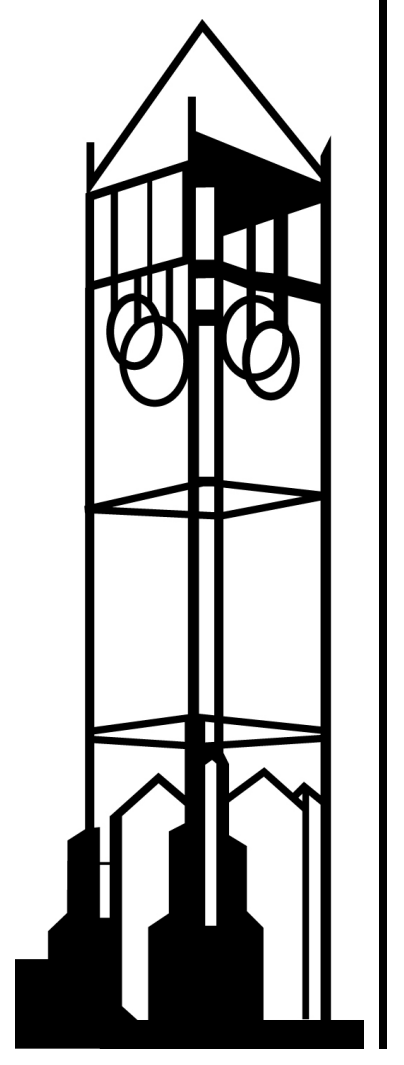

Working Paper No. 11019

November 2013

Revised on November 2013

IOWA STATE UNIVERSITY

Department of Economics

Ames, lowa, 50011-1070

lowa State University does not discriminate on the basis of race, color, age, religion, national origin, sexual orientation, gender identity, genetic information, sex, marital status, disability, or status as a U.S. veteran. Inquiries can be directed to the Director of Equal Opportunity and Compliance, 3280 Beardshear Hall, (515) 294-7612. 


\title{
Disentangling Demand-Enhancing and Trade-Cost Effects of Maximum Residue Regulations
}

\author{
Bo Xiong and John Beghin \\ Working Paper 13-WP 544 \\ November 2013 \\ Center for Agricultural and Rural Development \\ lowa State University \\ Ames, lowa 50011-1070 \\ www.card.iastate.edu
}

Bo Xiong, boxiong@ucdavis.edu, the corresponding author, is a postdoctoral researcher at the Agricultural Issues Center, University of California. One Shields Avenue, Davis, CA 95616. (530)304-9608. John Beghin, beghin@iastate.edu, is the Marlin Cole Professor of International Agricultural Economics at the Department of Economics, lowa State University. 260 Heady, Ames, IA 50011. (515)294-5811.

The authors thank the editor and two anonymous referees for helping improve the article, Yuan Li for generously sharing the data, Chengyan Yue and Lan Liu for commenting on an earlier draft, and Jonathan Barker for his careful proofreading.

This publication is available online on the CARD website: www.card.iastate.edu. Permission is granted to reproduce this information with appropriate attribution to the author and the Center for Agricultural and Rural Development, lowa State University, Ames, lowa 50011-1070.

lowa State University does not discriminate on the basis of race, color, age, ethnicity, religion, national origin, pregnancy, sexual orientation, gender identity, genetic information, sex, marital status, disability, or status as a U.S. veteran. Inquiries can be directed to the Interim Assistant Director of Equal Opportunity and Compliance, 3280 Beardshear Hall, (515) 294-7612. 


\title{
Disentangling Demand-Enhancing and Trade-Cost Effects of Maximum Residue Regulations
}

\author{
Bo Xiong and John Beghin
}

\begin{abstract}
Maximum residue levels (MRLs) regulations in plant products can create unnecessary trade barriers on one hand and enhance demand via risk mitigation or quality assurance on the other. We stipulate a generalized gravity equation model to disentangle the effects of MRLs on the import demand and foreign exporters' supply. Applying the framework to the MRLs on pesticides imposed by high-income OECD countries, we find that the MRLs jointly enhance the import demand and hinder foreign exporters' supply. In addition, exporters from the less and least developed countries are more constrained by the MRLs than their competitors from the developed world.
\end{abstract}

Keywords: maximum residue level, sanitary and phytosanitary, food safety, nontariff barriers, gravity model.

JEL classifications: F14, Q17 


\section{Introduction}

The Agreements on the Application of Sanitary and Phytosanitary (SPS) Measures and Technical Barriers to Trade (TBT) of the World Trade Organization (WTO) have been effective since 1995. The two agreements are designed to reconcile the member countries’ right to apply SPS and TBT measures to achieve legitimate policy objectives, such as the protection of human health and the environment, while keeping the resulting trade distortion to a minimum. Over the past decade, the Dispute Settlement Body of the WTO dealt with an increasing number of trade disputes citing either the SPS or the TBT agreement and claiming that certain regulations had created unnecessary trade barriers and constituted protectionism in disguise (World Trade Report, 2012).

The implications of SPS measures and TBTs for international market access and welfare are more complex than those of traditional price-based trade barriers, such as tariffs and countervailing duties, because SPS and TBT regulations often address market imperfections. The corrective role of SPS measures and TBTs ranges from alleviating asymmetric information in the marketplace (e.g., labeling requirements) to mitigating risk in the consumption of certain products (e.g., restrictions on aflatoxin contaminants in edible nuts) and enhancing the sustainability of the eco-system (e.g., quarantine policies preventing exotic pests and diseases invasion). Therefore, SPS measures and TBTs are likely to affect both consumers and producers' incentive structures and alter their behavior accordingly.

From the perspective of producers and processors, the cost of complying with the SPS or TBT regulations can be high. The fixed costs may include the upgrade of practice codes and facilities, the acquisition of certificates, conformity in marketing requirements, 
etc. In addition, inspection and testing procedures at custom points may cause prolonged delivery time, rejection of certain shipments, or even denial of entry completely. ${ }^{1}$

Therefore, the proliferation of SPS measures and TBTs can significantly reduce a country's imports from its trading partners, and even drive some foreign suppliers out of the market. This is the trade-cost effect, which corresponds to the "standards as barriers" argument in the international development literature (e.g., Otsuki, Wilson, and Sewadeh, 2001; Anders and Caswell, 2009). ${ }^{2}$

On the other hand, SPS measures and TBTs may enhance a country's demand for imports if the regulations address market imperfections (Thilmany and Barrett, 1997). For example, mandatory labeling requirements in meat products can boost meat demand by conveying quality information to consumers (Bureau, Marette, and Schiavina, 1998). Alternatively, SPS policies can promote social well-being, in the form of better public health, higher animal welfare, or more sustainable environment. ${ }^{3}$ In economies where the consumer awareness of food safety, animal welfare, and plant health is high, the SPS measures could stimulate more demand for products under regulation (Josling, Roberts, and Orden, 2004). This is the demand-enhancing effect of SPS measures and TBTs, corresponding to the "standards as catalyst" argument in the literature.

Therefore, SPS measures and TBTs either facilitate or hinder international trade, depending on whether the demand-enhancing effect, if any, outweighs or falls short of the trade-cost effect. This dual effect calls for a different analytical framework from those used

\footnotetext{
${ }^{1}$ See for example the U.S. monitoring programs for food imports at http://www.accessdata.fda.gov/scripts/importrefusals/

${ }^{2}$ Note that the trade-cost effect is net of any efficiency gains from better production or distribution practice induced by the SPS/TBTs. See Jaffee and Henson (2005) for more details.

${ }^{3}$ See Peterson and Orden (2008) for an example of U.S. import ban on Mexican avocadoes (1915-1997) due to the concern of invasive exotic species.
} 
to analyze conventional trade taxes. ${ }^{4}$ The conventional wisdom that trade liberalization improves market access and welfare does not necessarily carry over to SPS measures and TBTs. For example, in a case study of antibiotic residues in crustaceans, Disdier and Marette (2010) show that tighter standards on antibiotic residues improve social welfare at the expense of contracted international trade.

In this article we provide a novel methodology to disentangle the dual effects of Maximum Residue Limits (MRLs), as a particular SPS measure, on the imports of plant products in high-income OECD countries. Exposures to pesticide and antibiotic residues through diet can be harmful to humans and especially children (Eskenazi, Bradman, and Castorina, 1999). Survey-based studies suggest that consumers value food safety such as the reductions in risk associated with pesticide residues (Eom, 1994). Consumers' valuation of risk mitigation provides incentives for importers and retailers to ensure acceptable level of food safety, for either legal or reputation causes (Henson and Caswell, 1999). Most governments mitigate food borne hazards by either banning the most toxic substances, or by limiting the degree of contamination in agricultural and food products.

Regulatory agencies can determine their own MRLs or rely on international standards such as MRLs set by Codex Alimentarius, a joint body of the UN World Health Organization and Food Agriculture Organization. Codex MRLs are science-based and considered least trade-distorting. In the United States, for example, these MRLs are regulated principally by the US Environmental Protection Agency with enforcement functions by the US Food and Drug Administration, US Department of Agriculture, and state enforcement agencies (USEPA, 2013). The EU, Australia, and Japan tend to have

\footnotetext{
${ }^{4}$ For example, Beghin, Disdier, and Marette (2012) apply the ad valorem equivalence approach to nontariff measures in agriculture and find that some non-tariff measures translate into negative trade taxes.
} 
MRLs much more stringent than the Codex MRLs whereas many other countries have their standards near or explicitly follow the Codex recommendations. A few developing countries such as Sri Lanka use lenient MRLs (Li and Beghin, 2012b).

Our proposed methodology identifies the demand-enhancing effect and the tradecost effect of MRL stringency separately based on one simple but essential fact: the same MRLs affect different trading partners differently. For an exporting country that already implements similarly stringent regulations at home, its exports to the market with a new MRL policy would be little interrupted, because its producers and handlers have learned to meet related regulations and are capable of meeting the MRL abroad at low cost. In contrast, for a source country with no MRLs, its export prospects to a foreign market would be severely impeded by MRLs in the destination market, because of the high compliance costs for meeting the new regime. ${ }^{5}$ Empirically, the differential impacts of MRLs on different exporters enable us to disentangle the two effects.

By investigating MRLs adopted by high-income OECD countries and their imports of plant products from major trading partners, we show that the MRLs jointly enhance the import demand for plant products and impede foreign supplier' access to the markets of high-income OECD countries. Moreover, we find evidence that exporters of plant products from less or least developed countries are more constrained by MRL stringency than their competitors from the developed world.

The rest of the article is organized as follows. In section 2, we provide a conceptual model leading to an econometric model in which the dual effects of MRLs are

\footnotetext{
${ }^{5}$ The differential impacts of SPS and TBTs on different exporters are well documented in the literature. For example, Disdier, Fontagné, and Mimouni (2008) show that SPS and TBTs in agriculture significantly reduce the OECD' imports from developing countries, but do not affect trade flows among the OECD members.
} 
disentangled. In section 3, we describe the data and present the empirical results. In the last section, we draw conclusions and discuss possible extensions.

\section{The modeling approach}

Our analytical framework characterizes the separate impacts of MRLs on the import demand for and the trading partners' supply of plant products. In equilibrium a generalized gravity equation model emerges, which lays the foundation for an empirical specification to be estimated in the next section.

\subsection{The import demand}

There is a representative consumer in country $j$ with preferences characterized by the Constant Elasticity of Substitution (CES) utility. All plant products are assumed differentiated by sectors and by country of origins (Armington, 1969). For example, “Japanese apples” and "U.S. apples” are distinct goods in the composite sector "apples.” As discussed in the previous section, MRL polices mitigate food borne risk and affect the import demand for the plant products under regulation. ${ }^{6}$

Specifically, the representative consumer in country $j$ maximizes its consumption utility subject to her budget constraint:

(1a) $\max _{Q_{s i j}^{d}} U_{j}=\left[\sum_{s} \sum_{i}\left(\delta_{s j} Q_{s i j}^{d}\right)^{\frac{\varepsilon-1}{\varepsilon}}\right]^{\frac{\varepsilon}{\varepsilon-1}}$

$$
\text { s.t. } \sum_{s} \sum_{i} P_{s i j} Q_{s i j}^{d}=Y_{j}
$$

where $\delta_{s j}$ is the representative consumer's perceived quality of good $s$; $Q_{s i j}^{d}$ is the consumer's quantity demanded for good $s$ produced by country $i ; \varepsilon$ is the constant

\footnotetext{
${ }^{6}$ The MRLs may also generate non-market values that are external to the consumer, such as risk mitigation in public health or environmental sustainability in the long run. We abstract from this positive externality because it is not reflected in the marketplace and the associated social values are difficult to measure.
} 
elasticity of substitution; $P_{s i j}$ is the price of good $s$ produced in country $i$ and sold in country $j ; Y_{j}$ is the national income of country $j$. The solution to the problem (1a)-(1b) leads to country $j$ 's import demand (in values) for good $s$ originated from country $i$ : (2) $\quad V_{s i j}^{d} \equiv P_{s i j} \cdot Q_{s i j}^{d}=\frac{\delta_{s j}^{\varepsilon-1} P_{s i j}^{1-\varepsilon}}{\Pi_{j}} Y_{j}$, where $\Pi_{j}=\sum_{s} \sum_{i} \delta_{s j}^{\varepsilon-1} P_{s i j}^{1-\varepsilon}$ is the consumer price index in country $j$. Note that, for $\varepsilon>1$, the above import demand is positively related to the importing country's income and the consumers' quality perception, but negatively related to the price of the good.

The information disclosed by the MRLs, among other factors, alters the consumer' preferences for the product. In particular, we parameterize $\delta_{s j}$ as

$$
\delta_{s j}=\delta_{s 0} \exp \left(\beta M R L_{s j}\right)
$$

where $\delta_{s 0}$ is the consumer's quality perception for good $s$ in absence of MRL regulation; $M R L_{s j}$ is the stringency index of MRLs for sector $s$ in country $j$, with larger index representing more stringent MRLs (i.e., lower tolerance levels) $;^{7} \beta$ is a parameter to be estimated that captures the degree to which the MRLs affect the import demand.

Intuitively, (3) characterizes the demand-enhancing effect, or the quality improvement effect, associated with the MRLs. As an implicit assumption in our characterization of the import demand, the MRLs apply to imports of all origins, which is consistent with the nondiscrimination principle of the WTO.

\subsection{The foreign exporters' supply}

There is a representative producer for each sector in each country. The goods sold

\footnotetext{
${ }^{7}$ See the next section for the definition of the stringency index.
} 
by this producer in different destinations are imperfect substitutes because she tailors the specifications of her products to the marketing requirements in each market. For example, U.S. apples targeting the Japanese market are grown and handled differently to conform to the SPS regulations in Japan (Calvin, Krissoff, and Foster, 2008). The representative producer for sector $s$ in country $i$ is endowed with a production capacity $Q_{s i}$ and a Constant Elasticity of Transformation (CET) technology (Geraci and Prewo, 1982; Bergstrand, 1985). ${ }^{8}$ The CET technology allows the producer to transform products for different destinations. The problem for the representative producer is to decide which markets to target and how much to sell in each destination. Denoting $\Omega_{s i}$ as the set of countries the representative producer for sector $s$ in country $i$ decides to serve, ${ }^{9}$ we characterize the producer's problem as

$$
\max _{\left\{Q_{s i j}^{s}\right\}_{\in \Omega_{s i}}} \sum_{j \in \Omega_{s i}} P_{s i j} Q_{s i j}^{s}
$$

$$
\text { s.t. }\left[\sum_{j \in \Omega_{s i}}\left(\tau_{s i j} Q_{s i j}^{s}\right)^{\frac{\eta-1}{\eta}}\right]^{\frac{\eta}{\eta-1}}=Q_{s i} \text {, }
$$

where $Q_{s i j}^{s}$ is country i's quantity of good s supplied to country $j ; \eta<0$ is the elasticity of transformation, with a large $\eta$ in absolute value meaning easier transformation; $\tau_{s i j}>1$ is the "iceberg melting" trade cost term: $\tau_{s i j}$ units of good $s$ have to be shipped out of country $i$ in order for one unit to arrive in country $j$. The solution to (4a)-(4b) results in country $i$ 's supply of good $s$ to country $j$, in values, as:

\footnotetext{
${ }^{8}$ The production capacity is fixed in the short run and exogenous to MRLs. We leave out the long-run effect of MRLs on the production capacity because our data set exhibit limited time variation.

${ }^{9}$ For tractability, we do not explicitly model the endogenous choice of $\Omega_{s i}$. However, we account for countries' self-selection to export by using the Heckman sample selection model in the empirical section. Interested readers are referred to Chaney (2008) for a theoretical characterization of firms' decisions to trade and Kim, Reimer, and Gopinath (2011) for an empirical application to Korean manufacturing firms.
} 
(5) $\quad V_{s i j}^{s} \equiv P_{s i j} \cdot Q_{s i j}^{s}=\frac{Q_{s i} \tau_{s i j}^{\eta-1}}{\Psi_{s i} P_{s i j}^{\eta-1}}$,

where $\Psi_{s i}=\left[\sum_{j \in \Omega_{s i}} \tau_{s i j}^{\eta-1} P_{s i j}^{1-\eta}\right]^{\frac{\eta}{\eta-1}}$ is the producer price index for sector $s$ in country $i$, reflecting the cost of exporting to all possible destinations. Note in (5) that the foreign exporter's supply is positively related to the production capacity of the exporting country and the price of the good, but negatively related to the cost of trading between countries.

The bilateral trade cost arises from various factors such as import tariffs, geographical distance between the two countries, cultural similarity, and the difference in MRL regulation in particular. As a convention in the gravity model, we parameterize the trade cost, $\tau_{s i j}$, as

$$
\begin{aligned}
\tau_{s i j}= & \left(1+\operatorname{Tar}_{s i j}\right)\left(1+D i s t_{i j}\right)^{b_{d}} \exp \left(-b_{p} L_{a n g_{i j}}\right) \exp \left(-b_{b} \operatorname{Bord}_{i j}\right) \exp \left(-b_{c} \operatorname{Col}_{i j}\right) \\
& \cdot \exp \left(-b_{r} \operatorname{Re}_{i j}\right) \exp \left(\gamma \max \left\{M R L_{s j}-M R L_{s i}, 0\right\}\right),
\end{aligned}
$$

where $\operatorname{Tar}_{s i j}$ is country $j$ 's tariff rate imposed on good $s$ from country $i$; Dist $_{i j}$ is the distance between country $i$ and $j$; $L_{a n g}$ is the common language dummy variable that equals one if the two countries use the same official language; $\operatorname{Bord}_{i j}$ is the common border dummy variable that equals one if the two countries are adjacent; $\mathrm{Col}_{i j}$ is the colonial dummy variable that equals one if the two countries had a colonial relationship in history; $\operatorname{Rel}_{i j}$ is the proportion of two populations that speak a common language; $\gamma$, $b_{d}, b_{b}, b_{c}, b_{r}$, all presumably positive, are parameters to be estimated.

The new source of trade cost in (6) is the difference in MRLs between trading partners. Intuitively, our characterization of the trade cost of MRLs highlights the differential impacts of MRLs on different exporting countries. Exporters from countries 
with lax or no MRL regulation ( $M R L_{s j}>M R L_{s i}$ ) have to overcome additional costs to reach the stringent limits required by the importing country. However, exporters who have been subject to tougher MRLs in their domestic markets $\left(M R L_{s j}<M R L_{s i}\right)$ are less likely to experience trade disruption from MRLs variation in the importing country, because of their capabilities to comply with the regulation at negligible or low cost. ${ }^{10}$ As a by-product, our characterization of the trade cost of MRLs naturally accommodates the harmonization of standards between countries. For example, MRLs do not cause additional cost of trade if both trading partners adopt international or regional standards.

\subsection{The equilibrium}

In equilibrium, consumers’ import demand equals foreign exporters’ supply in each sector and for any pair of countries. By imposing the market clearing condition $V_{s i j}^{d}=V_{s i j}^{s}$, we solve for the equilibrium trade value, $V_{s i j}$, and the equilibrium price, $P_{s i j}$, in sector $s$ and for exporting country $i$ and importing country $j$. Specifically, (2) and (5) lead to

$$
P_{s i j}=\left(\frac{Y_{j}}{\Pi_{j}}\right)^{\frac{1}{\varepsilon-\eta}}\left(\frac{\Psi_{s i}}{Q_{s i}}\right)^{\frac{1}{\varepsilon-\eta}} \delta_{s j}^{\frac{\varepsilon-1}{\varepsilon-\eta}} \tau_{s i j}^{\frac{1-\eta}{\varepsilon-\eta}}, \quad \text { and }
$$

$$
V_{s i j}=\left(\frac{Y_{j}}{\Pi_{j}}\right)^{\frac{1-\eta}{\varepsilon-\eta}}\left(\frac{Q_{s i}}{\Psi_{s i}}\right)^{\frac{\varepsilon-1}{\varepsilon-\eta}}\left(\frac{\delta_{s j}}{\tau_{s i j}}\right)^{\frac{(\varepsilon-1)(1-\eta)}{\varepsilon-\eta}}
$$

Equation (7a) suggests that the equilibrium price is increasing in the importing country's income level, $Y_{j}$, the perceived quality of the imports, $\delta_{s j}$, and the trade cost between the two countries, $\tau_{s i j}$; but it is decreasing in the exporting country's total supply, $Q_{s i}$.

\footnotetext{
${ }^{10}$ Our characterization of the trade cost of MRLs is similar to the heterogeneity index used by Winchester et al. (2012) and Liu and Yue (2013).
} 
Equation (7b) shows that the bilateral trade value is increasing in the importing country's income level, $Y_{j}$, the exporting country's capacity, $Q_{s i}$, and the quality of the imports, $\delta_{s j}$; but it is decreasing in the trade cost between the two countries, $\tau_{s i j}$. Substituting (3) and (6) into (7b) and taking the logarithmic transformation, we arrive at the following characterization of bilateral trade values in equilibrium:

$$
\begin{aligned}
& \ln \left(V_{s i j}\right)=\varphi Y_{j}-\varphi \Pi_{j}+(1-\varphi) Q_{s i}-(1-\varphi) \Psi_{s i}-\theta \ln \left(1+\operatorname{Tar}_{s i j}\right)+\theta b_{l} L_{a n g}-\theta b_{d} \ln \left(1+\text { Dist }_{i j}\right) \\
& +\theta b_{b} \operatorname{Bord}_{i j}+\theta b_{c} \operatorname{Col}_{i j}+\theta b_{r} \operatorname{Rel}_{i j}-\theta \gamma \max \left\{M R L_{s j}-M R L_{s i}, 0\right\}+\theta \beta M R L_{s j},
\end{aligned}
$$

where $\varphi=(1-\eta) /(\varepsilon-\eta)$ and $\theta=(\varepsilon-1)(1-\eta) /(\varepsilon-\eta)$.

Equation (8) forms a generalized gravity equation model in which the demandenhancing effect and the trade-cost effect of MRLs are identified separately. ${ }^{11}$ When an importing country increases its stringency (variable $M R L_{s j}$ becomes larger), both effects are at work. On one hand, the more stringent regulation boosts the import demand because of the informational gain or the quality improvements associated with the new regulation. On the other hand, the tightening of the MRLs imposes additional costs upon the foreign supplies. This extra hurdle can be either significant or trivial, depending on whether the foreign supplies have been subject to similar regulations in their home markets. The differential impacts of MRLs on exporters of different origins allow us to disentangle the two effects in empirical applications.

By disentangling the dual effects of MRLs on international trade, our conceptual model leads to more plausible policy implications based on fundamental factors in the

\footnotetext{
${ }^{11}$ See Evenett and Keller (2002) or Feenstra, Markusen, and Rose (2003) for the linkage of the gravity model to various trade theories. See Novy (2013) for a recent study of global trade costs using a variant of the gravity model.
} 
world market for agricultural products. In particular, our model explicitly captures how both sides of the market react to MRLs, which enables us to better interpret the evidence accumulated in the literature. For example, Xiong and Beghin (2012) find that EU' harmonization and tightening of aflatoxin residue standards in 2002 has not significantly reduced Africa's groundnut exports to Europe. The negligible net effect of the MRL is consistent with either an inconsequential regulation, or the two significant effects on EU groundnut demand and Africa's groundnut supply cancelling out. Policy implications are drastically different between the two cases. While the former scenario requires no action, the latter case suggests that technical assistance to groundnut producers and processors in Africa would help them reap the high premium of safer groundnuts. Our disentangling approach can be used to discern the two cases and offer relevant policy recommendations.

\section{The empirical application}

We apply the above model to examine the impacts of MRLs adopted by high-income OECD countries on their imports of plant products. The literature provides mixed evidence regarding the conventional wisdom that the MRLs distort international trade in agricultural commodities. The estimated impact of MRLs on trade is sensitive to the products of concern, the country groups of interest, and to some extent the estimation methods, spanning from significantly trade-impeding to significantly trade-facilitating ( $\mathrm{Li}$ and Beghin, 2012a). Related to our investigation, Winchester et al. (2012) find weak evidence that the difference in MRLs on pesticides and veterinary drugs between EU and its trading partners hinders EU's imports of plant and animal products, but without accounting for possible demand enhancement effects. By disentangling the dual effects of MRLs, we improve upon the existing literature and offer a cogent rationalization of these 
various outcomes.

\subsection{The empirical strategy}

The conceptual model, characterized by (8), provides a basis for the empirical specification. One caveat in the execution is to appropriately account for the effects of two unobservable factors, $\Pi_{j}$ and $\Psi_{s i}$. As suggested by Anderson and van Wincoop (2003), the two price indices can be interpreted as the multi-lateral trade resistance terms in the importing and the exporting country respectively. Feenstra (2003) further shows that importers' and exporters' fixed effects can fully control for the effects of these price indices in cross-sectional analyses. A panel analysis would require the inclusion of yearspecific importers’ fixed effects and year-and-sector specific exporters’ fixed effects in the specification. To reduce the dimension of the econometric specification, we use yearspecific importers’ fixed effects and year-and-chapter specific exporters’ fixed effects. ${ }^{12}$ Note that the income effects in the importing countries are entirely absorbed by the yearspecific importers’ fixed effects.

To accommodate zero trade flows, we use the Heckman sample selection model (Heckman, 1979). The Heckman model has two major advantages. First, it explains the absence of trade by exporters' self-selection, which is consistent with the new trade theory featuring heterogeneous firms and fixed costs. ${ }^{13}$ Second, the Heckman model allows exploring the impacts of MRLs through affecting both the volume of trade, or the intensive margin, and the propensity to trade, or the extensive margin. From the

\footnotetext{
${ }^{12}$ Specifically, our data set covers 4 years, 60 exporting countries, and 109 plant products falling into 6 HS chapters. Replacing year-and-sector specific exporters' fixed effects with year-and-chapter specific exporters' fixed effects reduces the dimension from $21160(=4 * 60 * 109)$ to $1440(=4 * 60 * 6)$.

${ }^{13}$ Another estimator capable of capturing zero trade flows is the Poisson Pseudo Maximum Likelihood (PPML) estimator (Santos Silva and Tenreyro, 2006). However, Martin and Pham (2008) show that PPML leads to biased estimates when zero trade is a censored outcome. The update by Santos Silva and Tenreyro (2011) does not address the issue of censoring either.
} 
perspective of international development, the effect along the extensive margin bears important policy implications because small traders are likely to be deprived of international market access, because of the food safety policies.

Consistent with (8), our empirical specification is as follows:

(9a)

$$
\begin{aligned}
\ln \left(T_{s i j t}\right) & =(1-\varphi) Q_{s i t}-\theta \ln \left(1+\operatorname{tar}_{s i j}\right)-\theta b_{d} \ln \left(1+\text { dist }_{i j}\right)+\theta b_{l} \text { Lang }_{i j}+\theta b_{b} \text { Bord }_{i j}+\theta b_{c} \operatorname{Col}_{i j} \\
& -\theta \gamma \max \left\{M R L_{s j t}-M R L_{s i t}, 0\right\}+\theta \beta M R L_{s i t}+f e_{j t}+f e_{h i t}+\varepsilon_{s i j t},
\end{aligned}
$$

$$
\begin{aligned}
D_{s i j t}^{*} & =\left(1-\varphi^{*}\right) Q_{s i t}-\theta^{*} \ln \left(1+\operatorname{tar}_{s i j}\right)-\theta^{*} b_{d}^{*} \ln \left(1+\text { dist }_{i j}\right)+\theta^{*} b_{l}^{*} \operatorname{Lang}_{i j}+\theta^{*} b_{b}^{*} B^{*} d_{i j}+\theta^{*} b_{c}^{*} \operatorname{Col}_{i j} \\
& +\sum_{k} \theta^{*} b_{r}^{k} R e l_{i j} \cdot f e_{k}-\theta^{*} \gamma^{*} \max \left\{M R L_{s i t}-M R L_{s i t}, 0\right\}+\theta^{*} \beta^{*} M R L_{s i t}+f e_{j t}^{*}+f e_{h i t}^{*}+v_{s i j t},
\end{aligned}
$$

$$
\ln \left(V_{\text {sijt }}\right)=\left\{\begin{array}{cl}
\ln \left(T_{\text {sijt }}\right) & \text { if } D_{\text {sijt }}^{*}>0 \\
\text { n.a. } & \text { otherwise }
\end{array},\right.
$$

where $T_{\text {sijt }}$ is the ideal amount of trade in the absence of countries' self-selection to the world market, $D_{s i j t}^{*}$ is a latent variable capturing the binary decision to trade or no trade, and $V_{\text {sijt }}$ is the actually observed trade flow. Variable $f e_{j t}$ is the fixed effect for the importing country $j$ in year $t, f e_{h i t}$ is the fixed effect for HS chapter $h$ in the exporting country $i$ in year $t$. Equation (9a) explains the size of bilateral trade while (9b) characterizes the likelihood that the two countries trade with each other. The two error terms in (9a) and (9b) may be correlated due to omitted trade determinants that affect both the size and the propensity of trade.

We estimate (9a)-(9c) jointly using the two-step procedure. ${ }^{14}$ The identification of the model requires an excluded variable that potentially affects the fixed cost of trade but

\footnotetext{
${ }^{14}$ Alternatively, one can estimate the system by the maximum likelihood approach. However, the computational complexity causes convergence problems in our application.
} 
not the variable cost of trade. Following Helpman, Melitz, and Rubinstein (2008), we choose the common religion variable as the exclude variable. ${ }^{15}$ Furthermore, to allow possible heterogeneity across agricultural sectors in the self-selection process, we use the interaction terms of the chapters' fixed effects with the common religion variable. ${ }^{16}$

Finally, we address the possible endogeneity of MRLs. Lobbying efforts of domestic industries can influence public policies, such as MRLs. However, it is unclear from the existing studies whether food safety policies are more driven by the protectionist motives or legitimate social objectives. ${ }^{17}$ In our application, the potential bias due to the endogeneity problem is limited because the fixed effects capture the difference in policy designs across countries and sectors to a large degree.

\subsection{The data}

MRLs are frequently updated by regulatory agencies across countries. We use two data sources for the MRL information: the global MRL database developed by the United States Department of Agriculture (USDA) and the Homologa database available from the Department of Environment, Food and Rural Affairs in the United Kingdom. The USDA database consolidates the currently effective MRLs on pesticides applied to plant products and veterinary drugs applied to animal products (USDA-FAS). These MRLs are listed by pesticide or drug type, by commodity, and by country (inclusive of Codex). The Homologa database contains historical MRLs but the country coverage was highly restricted to the developed world prior to 2008. We take two cross-sections of the global MRL regulations: 2008 from Homologa and 2012 from USDA-FAS.

\footnotetext{
${ }^{15}$ Our choice is also justified by the pragmatic reason that the common religion variable is statistically insignificant in the simple OLS regression based on (9a).

${ }^{16}$ We thank the editor for this suggestion.

${ }^{17}$ See the World Trade Report (2012) for a summary of case studies of the political economy of SPS measures and TBTs.
} 
To measure the restrictiveness of the MRL regulation toward a given product in a given country, we follow Li and Beghin (2012b) and define the following stringency index of MRLs:

(10) $M R L_{j k}=\frac{1}{N_{(k)}} \sum_{n_{(k)}=1}^{N_{(k)}} \exp \left(\frac{M R L_{c o d e x, k n_{(k)}}-M R L_{j k n_{(k)}}}{M R L_{c o d e x, k n_{(k)}}}\right)$,

where $M R L_{j k n_{(k)}}$ is the MRL adopted by country $j$, for product $k$, and targeting pesticide $n_{(k)} ; M R L_{\text {codex, }, n_{(k)}}$ is the MRL recommended by Codex for the same product and pesticide combination; and $N_{(k)}$ is the total number of pesticides applicable to product $k \cdot{ }^{18}$ According to (10), the tougher a country's MRL regulation towards a product, the larger the index is for that combination of country and product. In addition, the stringency index reduces to one if a country defers to the Codex completely. An index above one would indicate that, averaging over various pesticide types, the MRL regulation is more restrictive than Codex for the product of interest and the country under consideration. ${ }^{19}$

Next we turn to the product and country coverage. Following Li and Beghin (2012b), we identify 109 plant products of which the commodity descriptions can be mapped with either the 4-digit or 6-digit product codes in the Harmonized System. ${ }^{20} \mathrm{We}$ focus on bilateral trade flows from 61 exporting countries to 20 importing countries. ${ }^{21}$ The selection of the exporting countries is based on the MRL data availability. The importing countries under consideration are 20 high-income OECD economies, where consumer awareness and valuation of food safety is arguably high and carries weight in

\footnotetext{
${ }^{18}$ Missing MRLs for some pesticides are replaced by the default tolerance levels in each country.

${ }^{19}$ See Li and Beghin (2012b) for more discussions of the properties of the stringency index.

${ }^{20}$ See Table A in Appendix A for the list of plant products.

${ }^{21}$ See Table B in Appendix B for the list of importing and exporting countries.
} 
public policies and retailer behavior. Consequently, the adopted MRLs are likely to affect the food demand and these countries are good candidates for our purpose.

To allow enough variations over time, we retrieve bilateral trade series from UNCOMTRADE for the year 2007, 2008, 2011, and 2012. We match the 2008's MRLs with trade flows in 2007 and 2008, and the 2012's MRLs with trade data in 2011 and 2012. The underlying assumption is that the MRL stringency does not vary significantly within two consecutive years (or even over the course of four years, as shown in Table 1 below). To proxy the production capacity in each sector in each country, or $Q_{\text {sit }}$, we sum the country's exports of the product to all destinations. ${ }^{22}$ We drop observations for which the potential exporting countries do not export to the rest of the world at all.

We also include other sources of bilateral trade costs. We use the tariff data from the Macmap database of the UNCTAD/WTO International Trade Centre. ${ }^{23}$ The tariff rates are ad valorem rates computed from national tariff lines as of $2010 .{ }^{24}$ Note that we choose the tariff year different from the trade years of interest to avoid the endogeneity issue in computing the tariff rates. As standard practice in gravity analysis, we also include cultural variables such as the colonial tie dummy variable, the common official language dummy variable, the common border dummy variable, and the distance variable are sourced from the CEPII database. ${ }^{25}$ In addition, we use the common religion variable from Helpman, Melitz, and Rubinstein (2008) as the excluded variable in our specification. In addition, we drop the trade flows within EU because the intra-EU trade is considered systematically freer than usual cross-border trade.

\footnotetext{
${ }^{22}$ Strictly speaking, our measurement of production should be interpreted as exportable production, because domestic consumption is not accounted for.

23 The database documentation and access are available at http://www.macmap.org/

24 The 2010 tariff information is unavailable for Korea, for which the 2007 rates are used.

${ }^{25}$ http://www.cepii.com/anglaisgraph/bdd/gravity.asp
} 
We present the summary statistics for the MRL stringency indices in Table 1. Averaging across 109 plant products and the 20 importing countries, the MRL stringency index is 1.34 in 2012 and 1.38 in 2008, which implies that pesticide control measures in the high-income OECD community are systematically tougher than the Codex standards. Although the MRL stringency is fairly constant over time, there is a trend among OECD countries, EU in particular, to loosen their MRLs and harmonize with the Codex recommendations. The MRL stringency index for an average country outside of the highincome OECD community is close to unity, indicating that the associated MRLs generally gravitate around the Codex levels.

The comparison of the stringency indices between trading partners reveals that more than 60 percent of bilateral trade records in the sample correspond to flows of plant products from countries with relatively lax MRL regulation to countries with relatively tougher standards. Trade flows in the reverse direction constitute slightly less than 30 percent of our sample. In addition, less than 10 percent of the trade flows occur between countries with equally stringent MRLs.

Table 1. Summary statistics for the MRL stringency indices

\begin{tabular}{|c|c|c|c|c|}
\hline \multirow[b]{2}{*}{ Variable } & \multicolumn{2}{|c|}{2012} & \multicolumn{2}{|c|}{2008} \\
\hline & Mean & Std. Dev. & Mean & Std. Dev. \\
\hline High-income OECD’ stringency index & 1.34 & 0.49 & 1.38 & 0.47 \\
\hline Other countries' stringency index & 1.01 & 0.18 & 1.02 & 0.24 \\
\hline \multicolumn{5}{|l|}{ Comparison of MRL stringency } \\
\hline & \multicolumn{2}{|c|}{ Frequency } & \multicolumn{2}{|c|}{ Frequency } \\
\hline MRL is tougher in the importing country & \multicolumn{2}{|l|}{$64 \%$} & \multicolumn{2}{|l|}{$68 \%$} \\
\hline MRL is tougher in the exporting country & \multicolumn{2}{|l|}{$29 \%$} & \multicolumn{2}{|l|}{$27 \%$} \\
\hline Equal stringency between trading partners & \multicolumn{2}{|l|}{$7 \%$} & \multicolumn{2}{|l|}{$5 \%$} \\
\hline
\end{tabular}




\subsection{Results and discussions}

Table 2 shows the estimated coefficients in the system (9a)-(9c). Both estimated effects of MRLs are statistically significant and bear the expected signs in the outcome equation. The evidence of the demand enhancement associated with MRLs lends support to the hypothesis that pesticide control measures alleviate information asymmetry by assuring the food safety of the products under regulation. Therefore, MRL regulation in plant products achieves legitimate public objectives and does not necessarily translate into protectionism. In the selection equation, we find that countries with tougher MRLs are more likely to import from other countries, and that the difference in MRL regulations has negligible implications for bilateral trade partnership.

Table 2. Estimated coefficients for high-income OECD's imports of plant products

\begin{tabular}{|c|c|c|c|c|c|}
\hline $\begin{array}{l}\text { Variable } \\
\text { \{parameter\} }\end{array}$ & $\begin{array}{l}\text { Outcome } \\
\text { Equation }\end{array}$ & $\begin{array}{l}\text { Selection } \\
\text { Equation }\end{array}$ & $\begin{array}{l}\text { Variable } \\
\text { \{parameter\} }\end{array}$ & $\begin{array}{l}\text { Outcome } \\
\text { Equation }\end{array}$ & $\begin{array}{l}\text { Selection } \\
\text { Equation }\end{array}$ \\
\hline $\begin{array}{l}\text { Demand shifter } \\
\{\theta \beta\}\end{array}$ & $\begin{array}{l}0.707^{* * *} \\
(0.052)\end{array}$ & $\begin{array}{l}0.152^{* * *} \\
(0.014)\end{array}$ & $\begin{array}{l}\ln \text { (Dist.) } \\
\left\{-\theta b_{d}\right\}\end{array}$ & $\begin{array}{l}-2.267 * * * \\
(0.051)\end{array}$ & $\begin{array}{l}-0.615^{* * *} \\
(0.008)\end{array}$ \\
\hline $\begin{array}{l}\text { Trade-cost shifter } \\
\{-\theta \gamma\}\end{array}$ & $\begin{array}{l}-0.250^{* * *} \\
(0.059)\end{array}$ & $\begin{array}{l}0.013 \\
(0.016)\end{array}$ & $\begin{array}{l}\text { Border } \\
\left\{\theta b_{b}\right\}\end{array}$ & $\begin{array}{l}0.529 * * * \\
(0.110)\end{array}$ & $\begin{array}{l}-0.240^{* * *} \\
(0.033)\end{array}$ \\
\hline $\begin{array}{l}\ln (\text { Prod }) \\
\{1-\varphi\}\end{array}$ & $\begin{array}{l}1.209 * * * \\
(0.016)\end{array}$ & $\begin{array}{l}0.228^{* * *} \\
(0.001)\end{array}$ & $\begin{array}{l}\text { Colony } \\
\left\{\theta b_{c}\right\}\end{array}$ & $\begin{array}{l}0.589 * * * \\
(0.057)\end{array}$ & $\begin{array}{l}0.121^{* * *} \\
(0.016)\end{array}$ \\
\hline $\begin{array}{l}\ln (\text { Tariff) } \\
\{-\theta\}\end{array}$ & $\begin{array}{l}-1.535^{* * *} \\
(0.112)\end{array}$ & $\begin{array}{l}-0.456 * * * \\
(0.030)\end{array}$ & $\begin{array}{l}\text { Language } \\
\left\{\theta b_{l}\right\}\end{array}$ & $\begin{array}{l}1.009 * * * \\
(0.049)\end{array}$ & $\begin{array}{l}0.309 * * * \\
(0.012)\end{array}$ \\
\hline $\begin{array}{l}\text { Inverse Mills } \\
\text { Ratio }\end{array}$ & $\begin{array}{l}3.629 * * * \\
(0.100)\end{array}$ & -- & \# of Obs. & 58,603 & 315,397 \\
\hline
\end{tabular}

Note: The year-specific importing countries' fixed effects and the year-specific and chapter-specific exporting countries' fixed effects are included in the regressions but omitted from the table for brevity. Chapter-specific common religion variables are used as the excluded variables. Standard errors are in parenthesis. Notations $*, * *$, and $* * *$ denote significance levels at $0.1,0.05$, and 0.01 respectively.

With regard to other sources of trade cost, import duties and distance are found to hinder trade in plant products, with both elasticities well above one. A common border increases the size of trade as commonly found in the literature, but the negative border 
effect on the decision to trade is unexpected. A closer look at the data reveals that the counter-intuitive result is driven by the fact that Israel trades much less frequently with its neighboring countries. Colonial relationships in history help create trade partnerships and enlarge the scale of trade. Countries with the same official language are more likely to trade than otherwise. Further, we find that countries with larger production capacities export more. In addition, the Inverse Mill's ratio is highly significant, which confirms that countries are self-selected to trade and justifies the use of the Heckman procedure.

To further explore the dual effects of MRLs on the intensive and extensive margins of trade, we compute the marginal effects of MRLs along both margins. This pursuit enables us to investigate whether MRLs influence international trade primarily through altering the size of trade or affecting the partnership between countries. Specifically, we define the marginal effects along the intensive margin as the impacts on the volume of trade in terms of elasticities. In the Heckman model, these marginal effects are identical to the raw estimates in the outcome equation. We define the marginal effects along the extensive margin as the impacts on the percentage change in the probability of trade. In the Heckman model, these marginal effects deviate from the raw estimates in the selection equation by a factor of the fitted probabilities of trade.

Table 3 presents the marginal effects of MRLs through both margins of trade. We find that tougher MRLs entice more demand primarily through the intensive margin, suggesting that the higher food safety would benefit established bilateral exchanges more than new ones. The costs associated with MRLs reduce the volumes high-income OECD import from supplying countries, but barely affect the likelihood of trade partnership. Furthermore, we test whether the net impact of importers’ MRLs is zero, given that both 
shifters are at work. Statistically, the hypothesis amounts to the parameter constraint $\theta \beta-\theta \gamma=0$. As shown in Table 3, the P-values for the Chi-square statistics lead us to reject the hypothesis that the overall impact of MRLs imposed by high-income OECD countries is negligible for their imports of plant products. Note that the net impact of MRLs is positive on high-income OECD members' imports of plant products, which invalidates the conventional wisdom that stringent food safety will impede trade. To put the results into economic perspective, we find that the high-income OECD members' imports of these products would decrease by nearly $12 \%$ if the member countries uniformly defer their MRLs to Codex recommendations.

Table 3. Marginal effects of MRLs on high-income OECD' import of plant products

\begin{tabular}{lll}
\hline & Intensive margin & Extensive margin \\
\hline Demand-enhancing effect & $0.707^{* * *}$ & 0.315 \\
& $(0.052)$ & $(0.295)$ \\
Trade-cost effect & $-0.250^{* * *}$ & 0.028 \\
& $(0.059)$ & $(0.043)$ \\
\hline
\end{tabular}

$H_{0}$ : the net effect of importer's MRLs is zero.

$\begin{array}{lll}\mathrm{P} \text { value for the test statistic } & 0.000 & 0.000\end{array}$

Note: Marginal effects are computed as the averages of marginal effects for individual observations. Standard errors in parenthesis are derived from the Delta method. Notations *, **, and $* * *$ denote significance levels at $0.1,0.05$, and 0.01 respectively.

In the less or least developed countries, their lack of financial and technological resources to comply with the MRLs adopted in the high-income OECD countries presumably puts their agricultural exporters at disadvantages in the world market. From the viewpoint of international development, it is interesting to investigate if the trade costs due to MRLs are disproportionally borne by exporters from the less or least developed world. To test this hypothesis, we split the entire sample into two sub-samples: South-to-North trade and North-to-North trade. Specifically, we refer to the 20 highincome OECD countries whose imports we focus on as North countries. In terms of per- 
capita income, the North countries are OECD members with per-capita income above 20,000 in 2012 US dollars. The group of the remaining 40 countries is referred to as South. Using the two sub-samples, we estimate system (9a)-(9c) again and report the estimated coefficients in Table 4 and the marginal effects in Table 5. 
Table 4. Estimated coefficients of high-income OECD' import of plant products from the South and the North

\begin{tabular}{|c|c|c|c|c|}
\hline & \multicolumn{2}{|c|}{ South-to-North } & \multicolumn{2}{|c|}{ North-to-North } \\
\hline $\begin{array}{l}\text { Variable } \\
\text { \{parameter\} }\end{array}$ & $\begin{array}{l}\text { Outcome } \\
\text { Equation }\end{array}$ & $\begin{array}{l}\text { Selection } \\
\text { Equation }\end{array}$ & $\begin{array}{l}\text { Outcome } \\
\text { Equation }\end{array}$ & $\begin{array}{l}\text { Selection } \\
\text { Equation }\end{array}$ \\
\hline $\begin{array}{l}\text { Demand shifter } \\
\{\theta \beta\}\end{array}$ & $\begin{array}{l}0.745^{* * *} \\
(0.068)\end{array}$ & $\begin{array}{l}0.155^{* * *} \\
(0.020)\end{array}$ & $\begin{array}{l}0.928^{* * * *} \\
(0.084)\end{array}$ & $\begin{array}{l}0.248^{* * * *} \\
(0.021)\end{array}$ \\
\hline $\begin{array}{l}\text { Trade-cost shifter } \\
\{-\theta \gamma\}\end{array}$ & $\begin{array}{l}-0.421 * * * \\
(0.077)\end{array}$ & $\begin{array}{l}-0.009 \\
(0.023)\end{array}$ & $\begin{array}{l}-0.259 * * * \\
(0.093)\end{array}$ & $\begin{array}{l}-0.041 \\
(0.025)\end{array}$ \\
\hline $\begin{array}{l}\ln (\text { Prod) } \\
\{1-\varphi\}\end{array}$ & $\begin{array}{l}1.182^{* * *} \\
(0.017)\end{array}$ & $\begin{array}{l}0.238 * * * \\
(0.001)\end{array}$ & $\begin{array}{l}1.144 * * * \\
(0.028)\end{array}$ & $\begin{array}{l}0.211^{* * *} \\
(0.003)\end{array}$ \\
\hline $\begin{array}{l}\ln \text { (Tariff) } \\
\{-\theta\} \\
\ln \text { (Dist.) } \\
\left\{-\theta b_{d}\right\}\end{array}$ & $\begin{array}{l}-0.345 * * * \\
(0.131) \\
-2.411 * * * \\
(0.059)\end{array}$ & $\begin{array}{l}-0.252 * * * \\
(0.038) \\
-0.694 * * * \\
(0.010)\end{array}$ & $\begin{array}{l}-2.477 * * * \\
(0.195) \\
-1.890 * * * \\
(0.091)\end{array}$ & $\begin{array}{l}-0.588 * * * \\
(0.048) \\
-0.560 * * * \\
(0.017)\end{array}$ \\
\hline $\begin{array}{l}\text { Border } \\
\left\{\theta b_{b}\right\}\end{array}$ & $\begin{array}{l}-0.327^{* *} \\
(0.140)\end{array}$ & $\begin{array}{l}-0.488 * * * \\
(0.040)\end{array}$ & $\begin{array}{l}2.019 * * * \\
(0.183)\end{array}$ & $\begin{array}{l}0.668 * * * \\
(0.083)\end{array}$ \\
\hline $\begin{array}{l}\text { Colony } \\
\left\{\theta b_{c}\right\}\end{array}$ & $\begin{array}{l}1.367^{* * *} \\
(0.070)\end{array}$ & $\begin{array}{l}0.314^{* * *} \\
(0.020)\end{array}$ & $\begin{array}{l}-0.310^{* * *} \\
(0.117)\end{array}$ & $\begin{array}{l}-0.089 * * * \\
(0.031)\end{array}$ \\
\hline $\begin{array}{l}\text { Language } \\
\left\{\theta b_{l}\right\}\end{array}$ & $\begin{array}{l}0.663^{* * *} \\
(0.056)\end{array}$ & $\begin{array}{l}0.229 * * * \\
(0.015)\end{array}$ & $\begin{array}{l}0.686^{* * *} \\
(0.102)\end{array}$ & $\begin{array}{l}0.212^{* * *} \\
(0.026)\end{array}$ \\
\hline $\begin{array}{l}\text { Inverse Mills } \\
\text { Ratio }\end{array}$ & $\begin{array}{l}3.371^{* * *} \\
(0.104)\end{array}$ & -- & $\begin{array}{l}3.199 * * * \\
(0.191)\end{array}$ & -- \\
\hline \# of Obs. & 42,667 & 235,160 & 15,936 & 80,237 \\
\hline
\end{tabular}

Note: The year-specific importing countries' fixed effects and the year-specific and chapterspecific exporting countries' fixed effects are included in the regressions but omitted from the table for brevity. Chapter-specific common religion variables are used as the excluded variables. Standard errors are in parenthesis. Notations $*, * *$, and $* * *$ denote significance levels at $0.1,0.05$, and 0.01 respectively. 
Table 5. Marginal effects of MRLs on high-income OECD' import of plant products from the South and the North

\begin{tabular}{|c|c|c|c|c|}
\hline & \multicolumn{2}{|c|}{ South-to-North } & \multicolumn{2}{|c|}{ North-to-North } \\
\hline & $\begin{array}{l}\text { Intensive } \\
\text { Margin }\end{array}$ & $\begin{array}{l}\text { Extensive } \\
\text { Margin }\end{array}$ & $\begin{array}{l}\text { Intensive } \\
\text { Margin }\end{array}$ & $\begin{array}{l}\text { Extensive } \\
\text { Margin }\end{array}$ \\
\hline $\begin{array}{l}\text { Demand- } \\
\text { enhancing } \\
\text { Effect }\end{array}$ & $\begin{array}{l}0.745^{* * *} \\
(0.068)\end{array}$ & $\begin{array}{c}0.334 \\
(0.464)\end{array}$ & $\begin{array}{l}0.928 * * * \\
(0.084)\end{array}$ & $\begin{array}{c}0.473 \\
(0.375)\end{array}$ \\
\hline $\begin{array}{l}\text { Trade-cost } \\
\text { Effect }\end{array}$ & $\begin{array}{l}-0.421^{* * * *} \\
(0.077)\end{array}$ & $\begin{array}{l}-0.020 \\
(0.057)\end{array}$ & $\begin{array}{l}-0.259 * * * \\
(0.093)\end{array}$ & $\begin{array}{l}-0.078 \\
(0.078)\end{array}$ \\
\hline $\begin{array}{l}\mathrm{H}_{0} \text { : zero net } \\
\mathrm{P} \text { value }\end{array}$ & $\begin{array}{l}\text { effect of imp } \\
0.000\end{array}$ & $\begin{array}{l}\text { rter's MRLs } \\
0.000\end{array}$ & 0.000 & 0.000 \\
\hline
\end{tabular}

Note: Marginal effects are computed as the averages of marginal effects for individual observations. Standard errors in parenthesis are derived from the Delta method.

Notations *, **, and $* * *$ denote significance levels at $0.1,0.05$, and 0.01 respectively. 
We first discuss the results in Table 4. In either the North-to-North or South-toNorth trade, we find consistent evidence that the MRLs adopted by high-income OECD countries affect both sides of the market in plant product. Moreover, the MRL regulations influence trade primarily through the intensive margin. We leave the discussion of the magnitudes of the dual effects until the marginal effects are derived, as shown in Table 5.

In terms of other sources of trade cost, we find that further tariff liberalization would benefit North-to-North trade more than South-to-North trade. One reason is that the less or least developed regions have been granted zero or low tariff rates, due to various regional and preferential trade agreements, so the potential gains from further tariff cut is diminishing. Geographic distance impedes South-to-North trade more than North-to-North trade, possibly due to their difference in logistics and other infrastructure. Historical colonial ties are more important for the partnership between South and North, rather than within North countries. The impacts of other trade determinants are similar as in the pooled regression.

Next we focus on the marginal effects of MRLs in Table 5. All marginal effects bear the expected signs and support the hypothesis that the MRL regulations improve food safety as well as impose additional costs of trade. Furthermore, MRLs affect international trade mostly by altering the size of trade between existing trade partners. Trade partnership, however, is not hindered by MRL stringency. We also find that the demand-enhancing effect is stronger for shipments from North countries than those from South countries. This result suggests that consumers concerning food safety might have origin preferences. More importantly, we find that MRLs hinder the export flows from the South more than those from the North. This finding implies that the producers and 
processors in the South countries have more difficulty complying with the MRL regulations imposed in high-income OECD countries. Overall, we find that the demandenhancing effect of MRLs outweighs its trade-cost effect for either imports from the North or the South. Therefore, MRLs as a policy tool to ensure food safety can achieve legitimate policy objectives without trade contraction.

\subsection{Diagnostic analysis}

One caveat in our econometric specification is the missing tariffs. In particular, we reduce the size of sample by nearly 15 percent by removing observations without tariff information in Macmap. To check the implications of the missing data problem, we keep the entire data sample but replace the tariff variable with a dummy variable indicating the engagement in one or more regional trade agreements between countries. ${ }^{26}$ Consequently, we gain more degree of freedom at the expense of rougher measurement of border taxes.

The supplementary results, shown in Appendix C, are qualitatively equivalent to the baseline results. In particular, we find that MRL stringency jointly enhance the import demand and hinder foreign exporters' supply. However, it is less clear that exporters from the South are more adversely affected than their competitors from the North. In addition, regional trade agreements facilitate international trade in plant products, as expected.

\section{Conclusions}

The increasing predominance of SPS measures and TBTs and their implications on international trade and development are vexing issues for stake holders and policy

\footnotetext{
${ }^{26}$ See http://www.wto.org/english/tratop_e/region_e/region_e.htm for a database for regional trade agreements available from the WTO.
} 
makers. In particular, a large number of the WTO trade disputes citing the SPS and TBT agreements concern agriculture and food sectors, where market imperfections are prevalent. The corrective role of SPS measures and TBTs calls for a different analytical framework that captures both the impacts on consumers and producers. In this article, we propose a generalized gravity equation model identifying the separate impacts of MRLs, an important form of SPS measures, on both sides of the market for food imports.

An application of our proposed model to high-income OECD countries’ imports of plant products delivers two robust results. First, MRLs enhances the import demand by ensuring higher food safety, as well as reduces export supply by imposing additional costs. Second, the compliance costs associated with MRLs put exporters from the less and least developed countries at a disadvantage in the world market for plant products. However, MRL stringency does not hinder the creation of new trade partnership. These findings contribute to the debate of SPS measures and TBTs. Our case study shows that the regulatory policies can achieve legitimate goals without impeding international trade in their cumulative effects. In addition, our proposed model helps rationalizing the mixed findings in the literature and provides analytical foundation that could be extended to welfare analysis.

Future research could investigate the welfare implications of MRLs, accounting for the external or social benefits, such as better human health in the long run. With a reasonable measurement the non-market values of MRLs, one can fully analyze the benefits and costs of MRLs and identify the MRLs that are socially optimal for the global market. 


\section{References}

Anders, S., and Caswell, J. (2009). Standards as barriers versus standards as catalysts: Assessing the impact of HACCP implementation on U.S. seafood imports. American Journal of Agricultural Economics 91: 310-321.

Anderson, J. and van Wincoop, E. (2003). Gravity with gravitas: A solution to the border puzzle. American Economic Review 93: 170-192.

Armington, P. (1969). A theory of demand for products distinguished by place of production. Staff Papers, International Monetary Fund 16: 159-178.

Beghin, J., Disdier, A.C., and Marette, S. (2012). Trade restrictiveness indices in presence of externalities: an application to non-tariff measures, WP \#12023, October 2012. Department of Economics, Iowa State University.

Bergstrand, J. (1985). The gravity equation in international trade: Some microeconomic foundations and empirical evidence. The Review of Economics and Statistics 67: 474-481.

Bureau, J. C., Marette, S., and Schiavina, A. (1998). Non-tariff trade barriers and consumers' information: The case of the EU-US trade dispute over beef. European Review of Agricultural Economics, 25: 437-462.

Calvin, L., Krissoff, B., and Foster W.E. (2008). Measuring the costs and trade effects of phytosanitary protocols: A U.S.-Japanese apple example. Review of Agricultural Economics 30: 120-135.

Chaney, T. (2008). Distorted gravity: The intensive and extensive margins of international trade. American Economic Review 98: 1707-1721.

Disdier, A-C, Fontagné, L., and Mimouni, M. (2008). The impact of regulations on 
agricultural trade: Evidence from the SPS and TBT agreements. American Journal of Agricultural Economics 90: 336-350.

Disdier, A. C., and Marette, S. (2010). The combination of gravity and welfare approaches for evaluating nontariff measures. American Journal of Agricultural Economics 92: 713-726.

Eom, Young Sook. (1994). Pesticide residue risk and food safety valuation: a random utility approach. American Journal of Agricultural Economics 76 (4): 760-771.

Eskenazi, B., Bradman, A., and Castorina, R. (1999). Exposures of children to organophosphate pesticides and their potential adverse health effects. Environmental health perspectives, 107 (Suppl 3): 409.

Evenett, S., and Keller, W. (2002). On theories explaining the success of the gravity equation. Journal of Political Economy 110: 281-316.

Feenstra, R. (2003). Advanced international trade: theory and evidence. Princeton University Press.

Feenstra, R., Markusen, J., and Rose, A. (2003). Using the gravity equation to differentiate among alternative theories of trade. Canadian Journal of Economics/Revue canadienne d'économique 34: 430-447.

Geraci, V., and Prewo, W. (1982). An empirical demand and supply model of multilateral trade. The Review of Economics and Statistics 64: 432-441.

Heckman, J. (1979). Sample selection bias as a specification error. Econometrica 47: 153-161.

Henson, S., and Caswell, J. (1999). Food safety regulation: an overview of contemporary issues. Food policy, 24: 589-603. 
Jaffee, S., and Henson, S. (2005). Agro-food exports from developing countries: the challenges posed by standards, global agricultural trade and developing countries, Chapter 6 in Aksoy, M. A., and Beghin, J. C. eds. Global Agricultural Trade \& Developing Countries. The World Bank.

Josling, T., Roberts, D., and Orden, D. (2004). Food regulation and trade. Toward a safe and open global system. Institute for International Economics.

Kim, S., Reimer, J. J., and Gopinath, M. (2011). The impact of trade costs on firm entry, exporting, and survival in Korea. Economic Inquiry 49: 434-446.

Li, Y., and Beghin, J. (2012a). A meta-analysis of estimates of the impact of technical barriers to trade. Journal of Policy Modeling 34: 497-511.

Li, Y., and Beghin, J. (2012b). Protectionism indices for non-tariff measures: an application to maximum residue levels, WP \#12013, July 2012. Department of Economics, Iowa State University.

Liu, L. and Yue, C. Investigating the impact of MRL standards' similarity on trade, Chapter 6, Non-Tariff Measures with Market Imperfections: Trade and Welfare Implications, ed. Beghin, J., Frontiers of Economics and Globalization series Emerald Press.

Martin, W. and Pham, C. (2008). Estimating the gravity model when zero trade flows are frequent. \#2008_03, Economics Series, School of Accounting, Economics, and Finance, Faculty of Business and Law, Deakin University.

Novy, D. (2013). Gravity redux: measuring international trade costs with panel data. Economic Inquiry 51: 101-121.

Otsuki, T., Wilson, J., and Sewadeh, M. (2001). Saving two in a billion: Quantifying the 
trade effect of European food safety standards on African exports. Food Policy 26: 495-514.

Peterson, E. B., and Orden, D. (2008). Avocado pests and avocado trade. American Journal of Agricultural Economics 90: 321-335.

Santos Silva, J. M., and Tenreyro, S. (2006). The log of gravity. The Review of Economics and Statistics 88: 641-658.

Santos Silva, J. M., and Tenreyro, S. (2011). Further simulation evidence on the performance of the Poisson pseudo-maximum likelihood estimator. Economics Letters, 112(2), 220-222.

Thilmany, D., and Barrett, C. (1997). Regulatory barriers in an integrating world food market. Review of Agricultural Economics 19: 91-107.

USDA-FAS. The International Maximum Residue Level Database. United States Department of Agriculture- Foreign Agricultural Service. http://www.mrldatabase.com/

USEPA. (2013). Setting Tolerances for Pesticide Residues in Foods. Pesticides: Topical \&ChemicalFact Sheets. http://www.epa.gov/pesticides/factsheets/stprf.htm\#other.

Winchester, N., Rau, M. L., Goetz, C., Larue, B., Otsuki, T., Shutes, K., Wieck, C., Burnquist, H., Pinto de Souza, M., Nunes de Faria, R. (2012). The Impact of Regulatory Heterogeneity on Agri-food Trade. The World Economy 35: 973-993.

World Trade Report 2012. Trade and public policies: A closer look at non-tariff measures in the $21^{\text {st }}$ century. The World Trade Organization.

Xiong, B., and Beghin, J. (2012). Does European aflatoxin regulation hurt groundnut exporters from Africa? European Review of Agricultural Economics 39: 589-609. 


\section{Appendix A}

Table A. Names of plant products, based on the Harmonized System

\begin{tabular}{|c|c|c|}
\hline Chapter & Description & Product names (HS 4 or 6 digits) \\
\hline HS-06 & live trees \& other plants & canna, chufa, dasheen \\
\hline HS-07 & edible vegetables & $\begin{array}{l}\text { artichoke, asparagus, bean*, broccoli, Brussels } \\
\text { sprouts, bulb onion, cabbage, cassava(roots), celery, } \\
\text { chickpea, chicory(tops), chrysanthemum, cucumber, } \\
\text { eggplant, endive, garden beet(roots), garlic, green } \\
\text { onion, lentil, lettuce(head), lettuce(leaf), mushroom, } \\
\text { non-bell pepper, olive, pea*, potato, spinach, squash, } \\
\text { sweet potato, tomato, turnip }\end{array}$ \\
\hline HS-08 & $\begin{array}{l}\text { edible fruits \& nuts, } \\
\text { peel of citrus/melons }\end{array}$ & $\begin{array}{l}\text { almond, apple*, apricot, avocado, blueberry, } \\
\text { beechnut, Brazil nut, cantaloupe, cashew, cherry, } \\
\text { chestnut, coconut, date, dry prune plum , fresh prune } \\
\text { plum, grape, grapefruit, guava, hazelnut, kiwifruit, } \\
\text { kumquat, loquat, nectarine, orange, papaya, peach, } \\
\text { pear, pineapple, pistachios, plantain, raisin, } \\
\text { strawberry*, tangelo, walnut, watermelon, } \\
\text { youngberry* }\end{array}$ \\
\hline HS-09 & coffee, tea, mate \& spices & ginger, pepper, summer savory \\
\hline HS-10 & Cereals & $\begin{array}{l}\text { barley, corn, corn salad, lupin, millet*, oat, rice, } \\
\text { sorghum, wheat }\end{array}$ \\
\hline HS-12 & $\begin{array}{l}\text { oil seeds/ misc. grains/ } \\
\text { med. plants/ straw }\end{array}$ & $\begin{array}{l}\text { cotton seed, hop(dried cones), mustard spinach, } \\
\text { peanut, sesame seed, sugar beet (roots) }\end{array}$ \\
\hline
\end{tabular}

Note: Products with * have multiple matches in the HS classifications. See Li and Beghin (2012b) for details. 


\section{Appendix B}

Table B. List of importing and exporting countries

\begin{tabular}{|c|c|c|c|c|c|c|}
\hline \multicolumn{2}{|c|}{ Importing countries } & \multicolumn{5}{|c|}{ Exporting countries } \\
\hline Australia & $\begin{array}{l}\text { New } \\
\text { Zealand }\end{array}$ & Algeria & $\begin{array}{l}\text { Domini- } \\
\text { can Rep. }\end{array}$ & Israel & Pakistan & Thailand \\
\hline Belgium & Portugal & Argentina & Ecuador & Italy & Panama & $\begin{array}{l}\text { Trinidad/ } \\
\text { Tobago }\end{array}$ \\
\hline Canada & $\begin{array}{l}\text { Rep. of } \\
\text { Korea }\end{array}$ & Australia & Egypt & Jamaica & Peru & Tunisia \\
\hline Denmark & Spain & Bahamas & $\begin{array}{l}\text { El } \\
\text { Salvador }\end{array}$ & Japan & Philippine & Turkey \\
\hline Finland & Sweden & Barbados & Finland & Jordan & Poland & $\begin{array}{l}\text { United } \\
\text { Arab } \\
\text { Emirates }\end{array}$ \\
\hline France & $\begin{array}{l}\text { United } \\
\text { Kingdoms }\end{array}$ & Belgium & France & Kenya & Portugal & $\begin{array}{l}\text { United } \\
\text { Kingdoms }\end{array}$ \\
\hline Germany & $\begin{array}{l}\text { United } \\
\text { States }\end{array}$ & Brazil & Germany & Lebanon & $\begin{array}{l}\text { Rep. of } \\
\text { Korea }\end{array}$ & $\begin{array}{l}\text { United } \\
\text { States }\end{array}$ \\
\hline Greece & & Canada & Greece & Malaysia & $\begin{array}{l}\text { Russia } \\
\text { Federation }\end{array}$ & Venezuela \\
\hline Ireland & & Chile & Guatemala & Mexico & Singapore & Vietnam \\
\hline Israel & & China & Honduras & Morocco & $\begin{array}{l}\text { South } \\
\text { Africa }\end{array}$ & \\
\hline Italy & & Columbia & $\begin{array}{l}\text { Hong } \\
\text { Kong }\end{array}$ & $\begin{array}{l}\text { Nether- } \\
\text { lands }\end{array}$ & Spain & \\
\hline Japan & & $\begin{array}{l}\text { Costa } \\
\text { Rica }\end{array}$ & Indonesia & $\begin{array}{l}\text { New } \\
\text { Zealand }\end{array}$ & Sri Lanka & \\
\hline $\begin{array}{l}\text { Nether- } \\
\text { lands }\end{array}$ & & Denmark & Ireland & Nicaragua & Sweden & \\
\hline
\end{tabular}




\section{Appendix C}

Table C. Estimated coefficients of high-income OECD' import of plant products from the South and the North, with tariff replaced by RTAs

\begin{tabular}{|c|c|c|c|c|}
\hline \multirow{3}{*}{ Variable } & \multicolumn{2}{|c|}{ South-to-North } & \multicolumn{2}{|c|}{ North-to-North } \\
\hline & Outcome & Selection & Outcome & Selection \\
\hline & Equation & Equation & Equation & Equation \\
\hline \multirow[t]{2}{*}{ Demand shifter } & $0.601^{* * *}$ & $0.091^{* * *}$ & $0.932 * * *$ & $0.288 * * *$ \\
\hline & $(0.065)$ & $(0.019)$ & $(0.075)$ & $(0.018)$ \\
\hline \multirow[t]{2}{*}{ Trade-cost shifter } & $-0.308 * * *$ & $0.046 * *$ & $-0.462 * * *$ & $-0.114 * * *$ \\
\hline & $(0.074)$ & $(0.023)$ & $(0.082)$ & $(0.022)$ \\
\hline \multirow[t]{2}{*}{$\ln$ (Prod) } & $1.192 * * *$ & $0.236 * * *$ & $1.120 * * *$ & $0.213 * * *$ \\
\hline & $(0.017)$ & $(0.001)$ & $(0.026)$ & $(0.003)$ \\
\hline \multirow[t]{2}{*}{ RTA } & $0.549 * * *$ & $0.274 * * *$ & $0.540 * * *$ & -0.003 \\
\hline & $(0.056)$ & $(0.015)$ & $(0.092)$ & $(0.025)$ \\
\hline \multirow[t]{2}{*}{$\ln$ (Dist.) } & $-2.221 * * *$ & $-0.575 * * *$ & $-1.689 * * *$ & $-0.580 * * *$ \\
\hline & $(0.054)$ & $(0.010)$ & $(0.082)$ & $(0.015)$ \\
\hline \multirow[t]{2}{*}{ Border } & -0.019 & $-0.278 * * *$ & $1.735^{* * *}$ & $0.649 * * *$ \\
\hline & $(0.140)$ & $(0.040)$ & $(0.177)$ & $(0.082)$ \\
\hline \multirow[t]{2}{*}{ Colony } & $1.336 * * *$ & $0.297 * * *$ & -0.165 & $-0.090 * * *$ \\
\hline & $(0.068)$ & $(0.019)$ & $(0.105)$ & $(0.028)$ \\
\hline \multirow[t]{2}{*}{ Language } & $0.732 * * *$ & $0.260 * * *$ & $0.459 * * *$ & $0.188 * * *$ \\
\hline & $(0.055)$ & $(0.014)$ & $(0.087)$ & $(0.023)$ \\
\hline Inverse Mills & $3.449 * * *$ & -- & $2.968 * * *$ & -- \\
\hline Ratio & $(0.101)$ & & $(0.175)$ & \\
\hline \# of Obs. & 46,412 & 270,690 & 18,555 & 98,351 \\
\hline
\end{tabular}

Note: RTAs refers to Regional Trade Agreements. The year-specific importing countries' fixed effects and the year-specific and chapter-specific exporting countries' fixed effects are included in the regressions but omitted from the table for brevity. Chapter-specific common religion variables are used as the excluded variables. Standard errors are in parenthesis. Notations $*, * *$, and $* * *$ denote significance levels at $0.1,0.05$, and 0.01 respectively. 